University of Nebraska - Lincoln

DigitalCommons@University of Nebraska - Lincoln

Identification of protein carbonyls in serum of the fetal and neonatal pig

Thomas J. Caperna

USDA-ARS, thomas.caperna@ars.usda.gov

Amy E. Shannon

USDA-ARS, amy.shannon@ars.usda.gov

Le Ann Blomberg

USDA-ARS, leann.blomberg@ars.usda.gov

Wesley M. Garrett

USDA-ARS, wesley.garrett@ars.usda.gov

Timothy G. Ramsay

Follow this and additional works at: https://digitalcommons.unl.edu/usdaarsfacpub

Part of the Agricultural Science Commons

Caperna, Thomas J.; Shannon, Amy E.; Blomberg, Le Ann; Garrett, Wesley M.; and Ramsay, Timothy G., "Identification of protein carbonyls in serum of the fetal and neonatal pig" (2010). Publications from USDA-ARS / UNL Faculty. 684.

https://digitalcommons.unl.edu/usdaarsfacpub/684

This Article is brought to you for free and open access by the U.S. Department of Agriculture: Agricultural Research Service, Lincoln, Nebraska at DigitalCommons@University of Nebraska - Lincoln. It has been accepted for inclusion in Publications from USDA-ARS / UNL Faculty by an authorized administrator of DigitalCommons@University of Nebraska - Lincoln. 


\title{
Identification of protein carbonyls in serum of the fetal and neonatal pig ${ }^{\text {t }}$
}

\author{
Thomas J. Caperna *, Amy E. Shannon, Le Ann Blomberg, Wesley M. Garrett, Timothy G. Ramsay

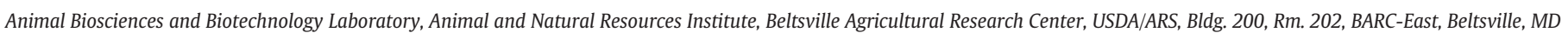 \\ 20705, USA
}

\section{A R T I C L E I N F O}

\section{Article history:}

Received 5 October 2009

Received in revised form 16 March 2010

Accepted 19 March 2010

Available online 27 March 2010

\section{Keywords:}

2D-PAGE

MALDI-TOF-MS

LCMS/MS

Protein oxidation

Runts

\begin{abstract}
A B S T R A C T
Oxidation of serum proteins leads to non-reversible carbonyl formation which alters their function and is associated with stress-related disease processes. The primary objective of this study was to quantify and identify oxidized serum proteins in fetal and newborn piglets. Protein carbonyls were converted to hydrazones with dinitrophenyl hydrazine and quantified spectrophotometrically. For identification, serum protein carbonyls were derivatized with biotin hydrazide, separated by 2D PAGE and stained with FITCavidin. Biotin-labeled proteins were excised from gels and identified by mass spectrometry. At birth, carbonyls were determined to be $\sim 600 \mathrm{pmole} / \mathrm{mg}$ serum protein. Fetuses at 50 and 100 days of gestation had similar levels of protein carbonyls as newborns. Carbonyl levels were also similar for control and runt $(<1 \mathrm{~kg}$ at birth) piglets between 1 and 21 days of age; however, distribution of many proteins varied by age and was also influenced by birth weight. Major oxidized proteins identified in fetal (f) and newborn ( $n$ ) pigs included; albumin ( $f, n)$, transferrin ( $f, n)$, fetuin-A (,$n$ ) alpha fetoprotein ( $f, n)$, plasminogen (f, n), fetuin-B (f), alpha-1-antitrypsin (f, n) alpha-1-acid glycoprotein (f) and immunoglobulins (n). While abundance and distribution of oxidized proteins changed over time, these changes appear to primarily reflect relative amounts of those proteins in serum.
\end{abstract}

Published by Elsevier Inc.

\section{Introduction}

Circulating and intracellular proteins are subject to many posttranslational modifications as a result of natural processes and in some cases, exogenous chemical insult. Such modifications are associated with alterations in the turnover rate, function, and activity of individual proteins which can have marked effects on downstream metabolism. Many proteins are oxidized following exposure to oxygen radicals which can be identified by the non-reversible carbonyl modifications of specific amino acids, typically proline, arginine, threonine, and lysine (Nyström, 2005). Additionally, several mechanisms including enzymemediated and metal catalyzed oxidation have been identified in the generation of protein carbonyls (Adams et al, 2001; Stadtman and Levine, 2000). Changes in oxidized proteins are associated with normal cellular events such as apoptosis, aging and cellular differentiation, as well as, disease processes including cancer, diabetes, Alzheimer's disease, and muscular dystrophy (Stadtman and Levine, 2000; Hernebring et al., 2006 and Dalle-Donne et al., 2006).

The studies reported here were undertaken to evaluate the potential role of protein oxidation in the developmental processes of the growing fetal and newborn pig. Our intent was to quantify the levels of protein

\footnotetext{
Mention of trade name, proprietary product or vendor does not constitute a guarantee or warranty of the product by the U.S. Department of Agriculture or imply its approval to the exclusion of other products or vendors that also may be suitable.

* Corresponding author. Tel.: + 1301504 8506; fax: + 13015048623.

E-mail address: thomas.caperna@ars.usda.gov (T.J. Caperna).
}

carbonyls and to identify which proteins were subject to oxidation. Because parturition stress is associated with increased levels of specific circulating protein carbonyls in humans (Marzocchi et al., 2005), we wanted to investigate the levels and identities of carbonylated proteins within the first $24 \mathrm{~h}$ of life to determine if the farrowing process was associated with enhanced oxidative stress in pigs. Moreover, we were particularly interested to see if the pattern of oxidized proteins in runt (or small for gestational age, SGA) piglets was indicative of increased susceptibility to oxidative insult around the time of birth, and during the early growth phase. Studies on extent of protein oxidation and distribution among specific proteins in serum of pigs have not been previously reported.

\section{Materials and methods}

\subsection{Reagents}

Chemicals for electrophoresis including acrylamide, bis-acrylamide, $\mathrm{N}, \mathrm{N}, \mathrm{N}^{\prime}, \mathrm{N}^{\prime}$-tetra-methyl-ethylenediamine (TEMED), ammonium persulfate, agarose, 3-[3-cholamidopropyl dimethylammonio]-1-propanesulfonate (CHAPS), Triton-X-100, ampholytes (Bio-Lytes, $\mathrm{pH} 3-10$ ), bromophenol blue (BPB), iodoacetamide, and sodium dodecyl sulfate (SDS) were purchased from Bio-Rad (Hercules, CA, USA). Trizma-Base (Tris), dithiothreitol (DTT), glycine, ammonium sulfate, ammonium bicarbonate, ethyl acetate, Coomassie blue G-250, trichloroacetic acid (TCA), biotin hydrazide, 2,4-dinitrophenylhydrazine (DNPH), sodium cyanoborohydride, and acetonitrile (ACN) were purchased from Sigma- 
Aldrich (St. Louis, MO, USA). Urea and avidin-fluorescein (avidin-FITC) were from Pierce (Rockford, IL). Methanol and acetic acid were from Fisher (Suwanee, GA, USA); trifluoroacetic acid (TFA) was from J.T. Baker (Phillipsburg, NJ, USA). All other chemicals were reagent or HPLC grade.

\subsection{Collection of serum samples}

Care and treatment of all pigs (Sus scrofa) in this study were approved by the Institutional Animal Care and Use Committee of the U.S. Department of Agriculture. Crossbred neonates (Landrace $\times$ York $\times$ Poland China) were obtained on day one (d1, within $24 \mathrm{~h}$ ), day seven ( $\mathrm{d} 7$ ) or 21 days (d21) after birth. Piglets were considered runts (or small for gestational age) if their birth weight was less than $1 \mathrm{~kg}$. Control piglets were sex-matched to the runts and were average in weight at birth for each litter. Fetal pigs at 50 days and between 90 and $110(100 \pm 3)$ days of gestation were harvested from electro-stunned gilts. Blood was collected by venous puncture and allowed to clot on ice. Serum was harvested by two successive centrifugation steps ( $3500 \mathrm{~g}$ in a swinging bucket rotor) and frozen in aliquots at $-80^{\circ} \mathrm{C}$ until analyzed. Protein content in whole serum and serum extracts was determined by the method of Lowry following precipitation in $7 \%$ trichloroacetic acid (TCA) and $0.07 \%$ Triton-X-100 (final concentrations, respectively) and resolubilized in $1 \mathrm{~N} \mathrm{NaOH}$ (Nerurkar et al., 1981). Bovine serum albumin was used as a standard.

\subsection{Quantification of protein carbonyls}

To quantify the amount of carbonyls in serum samples, the spectrophotemetric method of Levine et al. (1990), and Yoo and Regnier (2004) was employed. Briefly, serum samples (1-1.5 mg protein) were placed in $1.5 \mathrm{~mL}$ centrifuge tubes, brought up to $0.5 \mathrm{~mL}$ with $\mathrm{dH}_{2} \mathrm{O}$ containing $0.4 \%$ Triton X-100 and were precipitated with an equal volume of $20 \%$ TCA. Precipitates were collected by centrifugation $\left(30,000 \mathrm{~g}, 20 \mathrm{~min}, 4^{\circ} \mathrm{C}\right)$ and $500 \mu \mathrm{L} \mathrm{DNPH}$ in $2 \mathrm{~N} \mathrm{HCl}$ was added. Following brief sonication with a microprobe, samples were incubated with end-over-end mixing for $1 \mathrm{~h}$ at room temperature, in the dark. Protein was precipitated again by addition of an equal volume of $20 \%$ TCA. 1 mL ethyl acetate:ethanol (1:1) solution was added to each pellet which was re-suspended by sonication. Following centrifugation, pellets were washed an additional two times with ethyl acetate:ethanol. All pellets were re-suspended by ultrasound. The final pellets were solubilized with $6 \mathrm{M}$ guanidine hydrochloride in $20 \mathrm{mM} \mathrm{KH}_{2} \mathrm{PO}_{4} /$ $10 \mathrm{mM} \mathrm{H}_{3} \mathrm{PO}_{4}$, $\mathrm{pH} 2.3$, and the absorbance at $362 \mathrm{~nm}$ was determined. Protein content of each dissolved sample was also determined and the extinction coefficient for DNP-conjugated carbonyls was considered to be $22,000 \mathrm{M}^{-1} \mathrm{~cm}^{-1}$ (Levine et al., 1990). To serve as background for each individual sample, a complete set of control duplicates was prepared by addition of $2 \mathrm{~N} \mathrm{HCl}$ (without the DNPH) to the TCAprecipitated serum samples, treated as described above and the obtained background values ( $\mathrm{pmol} / \mathrm{mg}$ protein) were subtracted from the DNPH experimental determinations.

\subsection{Identification of protein carbonyls: biotin conjugation}

To separate, visualize, and identify carbonylated proteins, biotin hydrazide at neutral $\mathrm{pH}$ was used as a carbonyl coupling reagent (Yoo and Regnier, 2004). Serum samples were precipitated with TCA as described above and incubated for $2 \mathrm{~h}$ at room temperature in $5 \mathrm{mM}$ biotin hydrazide with end-over-end mixing. Samples were then reduced with sodium cyanoborohydride ( $15 \mathrm{mM}$ final concentration), and precipitated with TCA. Precipitates were washed with ethyl acetate: ethanol as described above. The final precipitates were vacuum dried, solubilized with modified 2D electrophoresis re-hydration buffer without DTT (7.55 M urea, 4\% CHAPS, 0.5\% Bio-Lytes and 0.001\% Bromophenol blue), and the total protein content was determined. Following separation by either 1D or 2D gel electrophoresis (as described below), the presence of biotin was confirmed by directly staining the gel with avidin-FITC (Nakamura et al., 2002; Yoo and Regnier, 2004). Individual samples which were labeled with biotin hydrazide and prepared for 2D electrophoresis were pooled after preparation so that equivalent amounts of protein from each of six (fetal) or seven (neonatal) piglets was mixed and each pooled sample was run and analyzed three (d1, d7, $\mathrm{d} 21$ ), four (fetal d50) or five (fetal d100) separate times. Prior to staining, gels were fixed in $50 \%$ ethanol $/ 3 \%$ acetic acid for 30 min, rinsed with PBS and incubated for $2 \mathrm{~h}$ in avidin-FITC $(22 \mu \mathrm{g} / \mathrm{mL})$; gels were rinsed in PBS containing $0.1 \%$ Tween-20, then "de-stained" overnight with PBS. Biotinavidin-FITC conjugates were visualized by fluorescence image scanning (488 nm excitation/520BP40 filter; Typhoon, GE Healthcare). Each gel was then fixed and stained with a standard colloidal Coomassie blue (CCB) stain (Caperna et al., 2008) and scanned (Image Scanner III, GE Healthcare, Piscataway, NJ, USA) to visualize total proteins.

\subsection{Two-dimensional polyacrylamide gel electrophoresis (2D-PAGE)}

The first dimension isoelectric focusing was performed using $7 \mathrm{~cm}$ immobilized pH gradient (IPG) gel strips ( $\mathrm{pH} 3-10$ Bio-Rad) in the IPGphor II system (GE Healthcare) essentially as previously described (Caperna et al., 2008). Briefly, re-hydration of pH 3-10 IPG strips was performed in the presence of $50 \mu \mathrm{g}$ protein and fresh DTT $(33 \mathrm{mM}$, final); gels were focused for a total of $10,000 \mathrm{kVh}$. Focused strips were rinsed in $\mathrm{dH}_{2} \mathrm{O}$ and stored at $-80^{\circ} \mathrm{C}$. Thawed strips were equilibrated, treated with iodoacetamide and the second dimension electrophoretic separation (10\% acrylamide) was performed as previously described (Caperna et al., 2008) using a mini-Protean II (Bio-Rad) electrophoresis system. Following electrophoresis, gels were fixed and stained as described above.

\subsection{In-gel digestion of proteins}

Coomassie-stained protein spots corresponding to FITC-avidinstained proteins were excised from the gel and placed in a 96-well $\mathrm{V}$

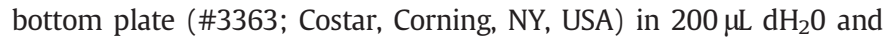
stored at $-80^{\circ} \mathrm{C}$. Samples obtained from gels were placed in an automated sample digester (Ettan Digester, GE Healthcare) using the protocol suggested by the manufacturer. Following addition of modified porcine trypsin, (sequencing grade, Promega, Madison, WI, USA), plates were covered with aluminum foil and incubated overnight at $25^{\circ} \mathrm{C}$. Samples punched from 1D gels were reduced with DTT and alkylated with iodoacetamide directly in a 96-well plate. The resulting tryptic fragments were extracted with $0.1 \%$ TFA in $50 \%$ acetonitrile. The extracts were dried to completeness by vacuum centrifugation, dissolved in $50 \%$ acetonitrile and $0.1 \%$ TFA, spotted $(0.5 \mu \mathrm{L})$ onto a target plate and cocrystallized with $\alpha$-cyanohydroxycinnamic acid (re-crystallized from Sigma \#C-2020) matrix.

\subsection{Mass spectrometry and protein identification}

A matrix-assisted laser desorption/ionization-time of flight mass spectrometer (Voyager DE-STR MALDI-TOF MS, Applied Biosystems, Framingham, MA) operated in positive ion reflector mode was used to analyze tryptic peptides by peptide mass fingerprinting (PMF). Spectra were acquired with 75 shots of a $337 \mathrm{~nm}$ Nitrogen Laser operating at $20 \mathrm{~Hz}$ and were internally calibrated using the porcine trypsin autolysis peaks at m/z 842.51 and 2211.10 as internal standards. Samples which were not initially identified by PMF were vacuum-dried, re-suspended in $20 \mu \mathrm{L} 5 \%$ acetonitrile, $0.1 \%$ formic acid and subjected to MS/MS analysis (ThermoFisher Scientific LTQ Orbitrap XL hybrid linear ion trap, Orbitrap mass spectrometer, San Jose, CA). Peptides were separated by reverse phase chromatography on a $100 \times 0.18 \mathrm{~mm}$ BioBasic- 18 column using a 30 min linear gradient from $5-40 \%$ acetonitrile in $0.1 \%$ formic acid at a flow rate of $3 \mu \mathrm{L} / \mathrm{min}$. The instrument was operated in data 
dependent mode with a duty cycle that acquired and recorded MS/MS spectra in the linear ion trap of the five most abundant ions determined by a high resolution survey scan in the Orbitrap $(r=30,000 @ \mathrm{~m} / \mathrm{z} 400)$ over the range of 400 to $1600 \mathrm{~m} / \mathrm{z}$. High mass accuracy of the survey scans was achieved and maintained by calibration in real time using the lock mass option. The polydimethylcyclosiloxane ion $\left(\mathrm{Si}\left(\mathrm{CH}_{3}\right)_{2} \mathrm{O}\right)_{6}$ (protonated $\mathrm{m} / \mathrm{z} 445.120025$ ) which is generated in the electrospray process from ambient air (Schlosser and Volkmer-Engert, 2003) was used for the calibration lock mass. Dynamic exclusion was employed to prevent the continuous analysis of the same ions. Once two MS/MS spectra had been acquired from any given ion, the parent mass was placed on an exclusion list for the duration of $3 \mathrm{~min}$. Electrospray voltage was set at $3.5 \mathrm{kV}$ and desolvation was assisted with 10 units of sheath gas; the capillary transfer tube temperature was set to $200{ }^{\circ} \mathrm{C}$. The minimum ion count required to trigger an $\mathrm{ms} / \mathrm{ms}$ spectrum was set to 5000 and normalized collision energy was set at $30 \%$. Mascot Distiller ver. 2.1.1 (www.matrixscience.com) was used to prepare searchable peak lists for both PMF data and LC-MS/MS data.

Protein identification by PMF or MS/MS was performed by searching the National Center for Biotechnology Information non-redundant (NCBInr) and SwissProt primary databases using the Mascot search engine which uses a probability based scoring system (Perkins et al., 1999). The following parameters were used for PMF database searches: monoisotopic mass, 25 ppm mass accuracy, trypsin as digesting enzyme with 1 missed cleavage allowed with a fixed modification of carbamidomethylation of cysteine, while oxidation of methionine, N-terminal pyroglutamic acid from glutamic acid or glutamine were set as variable modifications; taxonomy was limited to Mammalia or other Mammalia. For MS/MS data, monoisotopic mass was chosen ,as well as, peptide tolerance was set to $5 \mathrm{ppm}$, MS/MS tolerance to $1 \mathrm{Da}$, and peptide charges set to $1^{+}, 2^{+}$and $3^{+}$. Cleavage enzyme, allowed missed cleavages and fixed and variable modifications were the same as for PMF searches. To qualify the MALDI-TOF-MS data as a positive identification, a protein's score (MOWSE) was equal to or exceeded the minimum significant score. Positive identification of proteins by MS/MS analysis required a minimum of two unique peptides, both with significant ion scores and with an apparent protein molecular weight within approximately $10 \mathrm{kD}$ of the expected mass of each protein. In cases where multiple proteins were potentially present in a single spot, the protein with the highest score and/or the greatest peptide representation was considered to be the identified protein of record or it was reported as a mixture.

\subsection{Image analysis}

Following fluorescence analysis, gels were stained with colloidal Coomassie blue, and scanned as described above. All raw image files (.gel files) were converted to .tif files with IQTL software (GE Healthcare) and evaluated with Progenesis SameSpots software version 3.1 (Nonlinear Dynamics USA Inc., Durham, NC, USA). To determine individual spot volumes, the gel regions to be incorporated in the analysis areas were sized uniformly, and gels were aligned to a single reference gel for each experimental grouping. Individual spot volumes were determined for avidin-stained gels and then the corresponding spots from the CCBstained gels were identified and quantified, separately. In this methodology, spot boundaries were automatically determined based on the three-dimensional nature of each spot and background was individually subtracted using the "lowest pixel on boundary" method; spot volume represents the sum total of pixel density within the spot perimeter. For each experimental group (fetal or neonatal piglets) spot volumes were normalized to a single reference gel by applying a unique algorithm (http://www.nonlinear.com/products/progenesis/samespots/faq/normalisation.asp) which assigns an overall gain factor for each gel. This technique effectively minimizes potential variabilities in staining and protein load, or other gel irregularities. All spot volume values were analyzed by GLM ANOVA (NCSS 2000, NCSS,LLC, Kaysville UT,USA) using either a $2 \times 3$ factorial model (neonatal piglet samples) or a twocomparison model (fetal samples) to evaluate differences among individual protein spots. Values of $P<0.05$ were considered different.

\section{Results}

Quantitative analysis of DNP-conjugated protein carbonyls in serum of fetal and neonatal pigs is presented in Table 1. The level of carbonyls in all groups of pigs was remarkably similar among the different groups of pigs analyzed, and average carbonyl content ranged between 0.62 and $0.81 \mathrm{nmole} / \mathrm{mg}$ serum protein. Further, no differences $(P>0.05)$ were observed by ANOVA when age, individual group, or weight at birth, were considered in the statistical model.

To determine the relative distribution and identity of serum proteins that were carbonylated in vivo, biotin hydrazide-treated samples were prepared and methods were utilized to visualize labeled proteins directly in one dimensional and two dimensional gels with avidin-FITC. Under labeling conditions utilized, background staining with the avidinFITC conjugate was found to be negligible (Fig. 1), indicating that the avidin-FITC stain was specific for the carbonyls labeled with biotin.

The separation of fetal serum samples by 2D PAGE that were subsequently stained for both biotinylated carbonyls and total protein (CCB) are shown in Fig. 2 with corresponding identities and quantitative spot analysis in Table 2. Most, but not all of the major fetal serum proteins have some level of carbonyls. Proteins identified as having detectable carbonyl staining were: alpha-1 acid glycoprotein, fetuin A, fetuin B, alpha-1 antitrypsin, alpha fetoprotein, albumin, plasminogen, and transferrin (Table 2). Carbonyls associated with fetuin B (spots 1,2) and the content of protein associated with those spots were markedly decreased between d50 and d100. In contrast, spot 33 (also fetuin B) was elevated with no corresponding change in protein. The protein content associated with transferrin (spots 9, 10 \& 11) decreased between $\mathrm{d} 50$ and $\mathrm{d} 100$, and while not reaching the level of significance, the carbonyl content was also decreased numerically. Further, for each transferrin spot pairing, the ratio of carbonyls:protein (avidin:CCB spot volume ratio) was similar. The carbonyl and protein content of alpha1-antitrypsin (spot 12) also decreased between d50 and d100. The protein content of the minor alpha-fetoprotein component (spot 8) decreased between $\mathrm{d} 50$ and $\mathrm{d} 100$ while the major component (spot 30) as well as the carbonyl content and the ratio of carbonyl:protein remained the same. The major albumin component (spot 7), alpha1-antitrypsin ( spot 12) and fetuin A ( spot 13) all increased between d50 and $\mathrm{d} 100$, as did the carbonyl content. No other differences were noted comparing carbonyl and protein content between 50 and 100 days of gestation.

Serum from d1, d7 and d21 neonates (controls and runts) were also separated by 2D PAGE and stained for both biotin and total protein (controls are shown Fig. 3) with all corresponding spot analysis data in Table 3. Proteins which were identified as having detectable carbonyl

Table 1

Quantitative analysis of DNP-conjugated protein carbonyls in fetal and neonatal serum proteins.

\begin{tabular}{lllllll}
\hline & Fetal & & & Neonatal & & \\
\cline { 2 - 3 } Age: & 50 days & 100 days & & 1 day & 7 days & 21 days \\
\hline pmol/mg serum protein & & & & & \\
Control & $722 \pm 55$ & $805 \pm 103$ & & $633 \pm 48$ & $656 \pm 53$ & $648 \pm 53$ \\
Runt & NA & NA & & $623 \pm 51$ & $694 \pm 61$ & $790 \pm 61$ \\
\hline
\end{tabular}

Data are means \pm SEM ( $n=6$ pigs per group for fetal pigs; 7 pigs per group for neonates). Piglets weighing $<1.0 \mathrm{~kg}$ at birth were considered runts. Weights $(\mathrm{kg})$ of neonatal animals utilized in the study were: d1Control (C), $1.52 \pm 0.06$; d1Runt (R), $0.74 \pm 0.05$; d7C, $2.81 \pm 0.21$; d7R, $1.67 \pm 0.15$; d21C, $5.52 \pm 0.39$; d21R, 4.18 \pm 0.2

Data were analyzed by Analysis of Variance (GLM ANOVA) where models included individual group comparisons, age, and weight at birth (viz., controls vs runts) was considered. No significant differences in protein carbonyl concentration were noted for any of the comparisons performed.

NA; not applicable. 


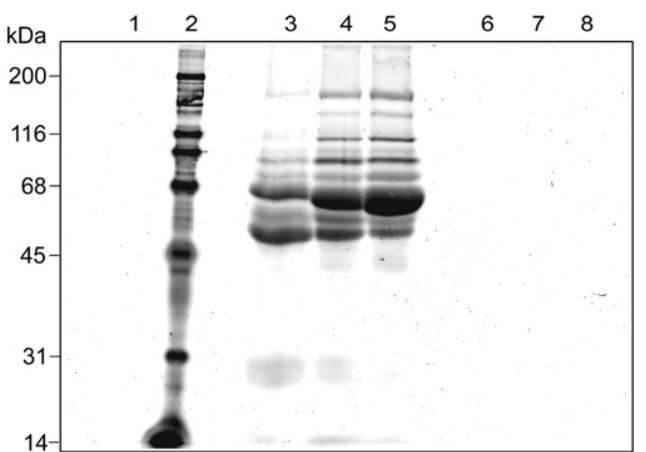

Fig. 1. Avidin-FITC-stained 1D gel of neonatal serum proteins labeled with or without biotin hydrazide. Lanes: (1) protein standard mix, (2) biotinylated protein standard mix (Broad range, Bio-Rad), (3, 4, \& 5 ) $20 \mu \mathrm{g}$ each of d1, d7 and d21 serum samples labeled with biotin hydrazide, $(6,7, \& 8), 20 \mu \mathrm{g}$ each of $\mathrm{d} 1$, d7, and d21 serum samples prepared with $2 \mathrm{~N} \mathrm{HCl}$ without biotin hydrazide.

staining were: fetuin A, alpha-1 antichymotrypsin, alpha fetoprotein, albumin, plasminogen, apolipoprotein A1, transferrin, immunoglobulin (heavy and light chains), and vitamin D binding protein.

Analysis of changes in protein carbonyls over time essentially corresponded to changes associated with protein content during the pre-weaning period. Both carbonyl content and total amounts of albumin (spots 1, 2, 16 \& 17) all increased between d1 and d21. Likewise the major protein components and carbonyls associated with transferrin (spots 3, 4, 12 \&14) were increased between d1 and d21. Plasminogen protein concentration tended to decrease over time [spots 8 \& $10(P<0.04)$, and possibly 9] while carbonyl content remained relatively constant. The carbonyl content and protein concentration of vitamin $\mathrm{D}$ binding protein and fetuin $\mathrm{A}$ also decreased between $\mathrm{d} 1$ and $\mathrm{d} 21(P<0.03)$. In all spots identified as immunoglobulin gamma chain, both the protein content and carbonyl content decreased over time. Interestingly, the relative carbonyl:CCB ratio varied greatly $(\sim 0.1-1.76)$ among the various isoforms of immunoglobulin heavy chains. Likewise, immunoglobulin light chains and the associated carbonyls were also reduced over time.

Statistical analysis of stained 2D gels identified a few differences in carbonyls and total proteins when runts and controls were compared. These include overall lower levels of immunoglobulin heavy chains (spots 22, 23, 25, 26, 27, 29, 30 \& 31) in runts compared to controls, however only spots 22 and 29 also had corresponding significant reductions in carbonyls associated with the lower levels of protein. The carbonyl content of an apparent high molecular weight variant of transferrin (spot 11) was significantly higher $(P<0.03)$ in runts compared to controls; however, due the proximity of this spot to other proteins in the CCB-stained gel, a specific protein spot volume could not be obtained. There was birth weight $\times$ age interaction on the total amount of fetuin A protein indicating that there was a higher amount of this protein in runts at birth, but not at later times; however the carbonyl content was not significantly influenced by birth weight. Finally, two proteins (spots 32 \& 33) which could not be identified by our methodology appear to be highly carbonylated at birth, particularly in runts; the carbonyl content rapidly declined over time with no corresponding change in protein content.

\section{Discussion}

In these studies, a combined analytical and proteomic approach was used to both quantify and identify specific oxidized proteins in serum of the perinatal pig. As discussed recently by Poon et al. (2007), the use of fluorescence-based in-gel imaging for protein carbonyls
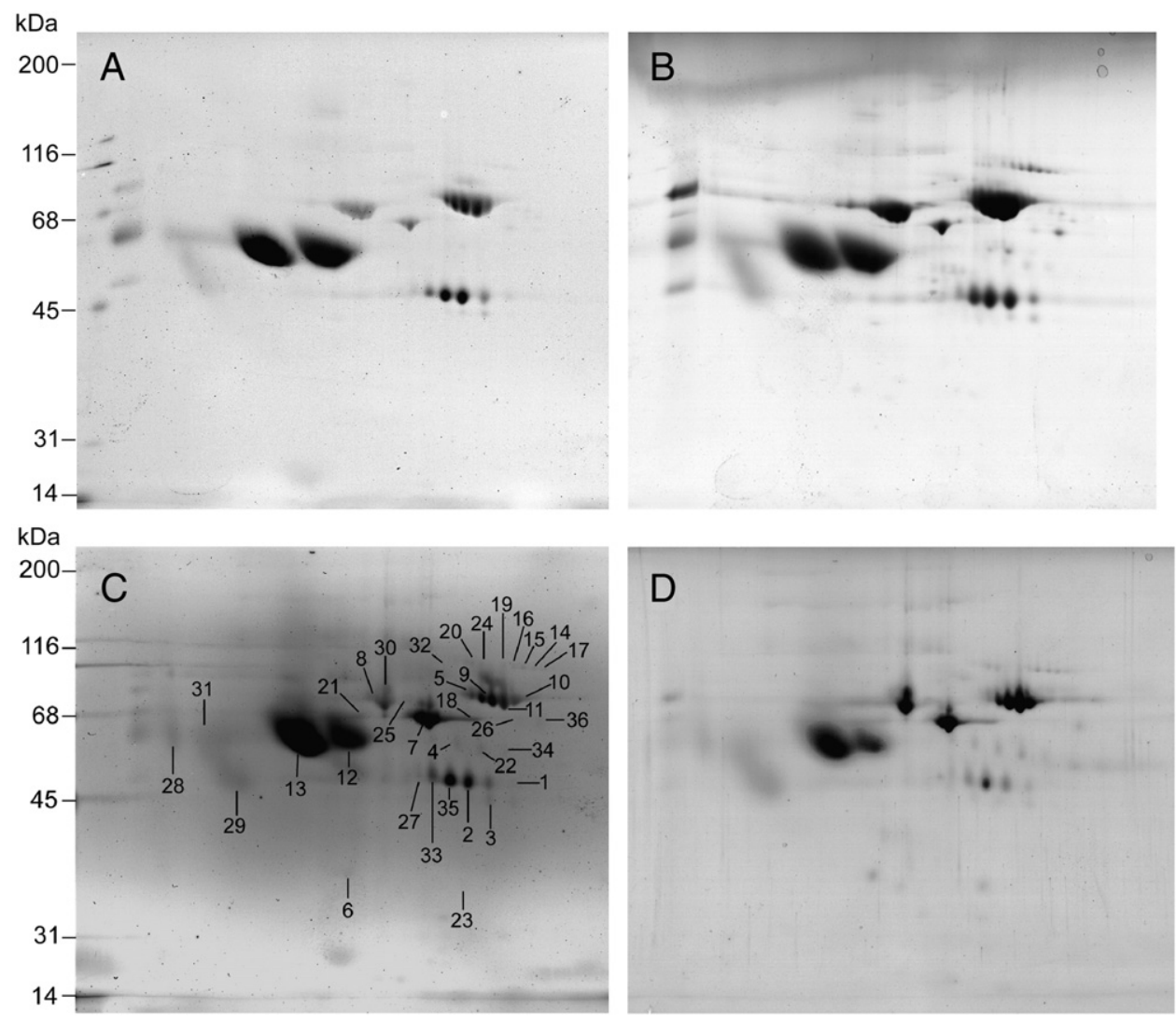

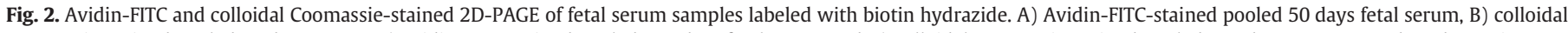

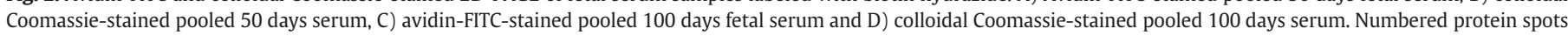
were identified by PMF or LC-MS/MS, see Table 2. In each gel pair, the same gel was stained with avidin-FITC and colloidal Coomassie blue. 
Table 2

Protein identification and distribution of carbonylated (avidin-stained) and total (ccb-stained) proteins in serum of fetal pigs at 50 and 100 days of gestation.

\begin{tabular}{|c|c|c|c|c|c|c|}
\hline \multirow[t]{2}{*}{ Gel spot } & \multirow[t]{2}{*}{ Protein ID } & \multirow[t]{2}{*}{ Stain } & 50 days & 100 days & $\mathrm{PSE}^{1}$ & \multirow[t]{2}{*}{$P<:^{2}$} \\
\hline & & & \multicolumn{3}{|c|}{ Spot volumes } & \\
\hline \multirow[t]{2}{*}{1} & Fetuin B & Avidin & 22.9 & 7.0 & 4.5 & 0.04 \\
\hline & & $\mathrm{CCB}$ & 47.8 & 7.3 & 2.7 & 0.01 \\
\hline \multirow[t]{2}{*}{2} & Fetuin B & Avidin & 139.5 & 47.0 & 17.2 & 0.01 \\
\hline & & $\mathrm{CCB}$ & 116.5 & 41.1 & 4.3 & 0.01 \\
\hline \multirow[t]{2}{*}{3} & Fetuin B & Avidin & 70.3 & 71.7 & 14.6 & $n s^{3}$ \\
\hline & & $\mathrm{CCB}$ & 98.6 & 41.0 & 8.5 & 0.01 \\
\hline \multirow[t]{2}{*}{4} & No ID $^{4}$ & Avidin & 35.1 & 43.6 & 5.8 & ns \\
\hline & & $\mathrm{CCB}$ & 26.5 & 59.4 & 5.2 & 0.01 \\
\hline \multirow[t]{2}{*}{5} & Transferrin & Avidin & 511.4 & 365.6 & 81.5 & ns \\
\hline & & $\mathrm{CCB}$ & 554.3 & 269.8 & 41.5 & 0.01 \\
\hline 6 & No ID & Avidin & 100.8 & 113.5 & 17.2 & ns \\
\hline & & $\mathrm{CCB}$ & 69.4 & 141.8 & 11.1 & 0.01 \\
\hline 7 & Albumin & Avidin & 437.0 & 1294.9 & 99.9 & 0.01 \\
\hline & & $\mathrm{CCB}$ & 639.2 & 1179.1 & 68.5 & 0.01 \\
\hline 8 & Alpha fetoprotein & Avidin & 326.3 & 202.9 & 66.0 & ns \\
\hline & & $\mathrm{CCB}$ & 638.0 & 384.6 & 53.8 & 0.01 \\
\hline 9 & Transferrin & Avidin & 628.1 & 518.1 & 67.4 & ns \\
\hline & & $\mathrm{CCB}$ & 660.4 & 420.7 & 18.7 & 0.01 \\
\hline 10 & Transferrin & Avidin & 1807.4 & 1261.5 & 192.0 & ns \\
\hline & & $\mathrm{CCB}$ & 2803.3 & 1892.8 & 262.8 & 0.04 \\
\hline 11 & Transferrin & Avidin & 1012.7 & 910.6 & 106.4 & ns \\
\hline & & $\mathrm{CCB}$ & 1277.2 & 914.9 & 31.2 & 0.01 \\
\hline 12 & Alpha-1-antitrypsin & Avidin & 2328.9 & 1642.0 & 194.4 & 0.04 \\
\hline & & $\mathrm{CCB}$ & 1598.6 & 1192.3 & 51.6 & 0.01 \\
\hline 13 & Fetuin A & Avidin & 8969.0 & 12113.4 & 803.0 & 0.03 \\
\hline & & $\mathrm{CCB}$ & 6621.8 & 7395.0 & 200.0 & 0.03 \\
\hline 14 & Plasminogen & Avidin & 10.5 & 12.2 & 4.3 & ns \\
\hline & & $\mathrm{CCB}$ & 33.7 & 14.2 & 8.1 & ns \\
\hline 15 & Plasminogen & Avidin & 8.7 & 8.9 & 3.1 & ns \\
\hline & & $\mathrm{CCB}$ & 31.6 & 15.9 & 6.8 & ns \\
\hline 16 & Plasminogen & Avidin & 15.2 & 22.5 & 7.4 & ns \\
\hline & & $\mathrm{CCB}$ & 34.9 & 19.5 & 7.1 & ns \\
\hline 17 & Plasminogen & Avidin & 8.7 & 6.9 & 2.3 & ns \\
\hline & & $\mathrm{CCB}$ & 25.1 & 14.1 & 5.7 & ns \\
\hline 18 & Albumin & Avidin & 28.0 & 49.3 & 10.0 & ns \\
\hline & & $\mathrm{CCB}$ & 40.2 & 66.2 & 13.1 & ns \\
\hline 19 & Plasminogen & Avidin & 10.6 & 17.0 & 4.4 & ns \\
\hline & & $\mathrm{CCB}$ & 18.1 & 11.4 & 4.9 & ns \\
\hline 20 & Properdin factor B & Avidin & 177.6 & 211.7 & 57.3 & ns \\
\hline & & $\mathrm{CCB}$ & 216.4 & 140.7 & 25.8 & ns \\
\hline 21 & Albumin & Avidin & 20.3 & 19.9 & 6.2 & ns \\
\hline & & $\mathrm{CCB}$ & 29.5 & 38.5 & 18.8 & ns \\
\hline 22 & No ID & Avidin & 37.6 & 46.2 & 6.1 & ns \\
\hline & & $\mathrm{CCB}$ & 55.0 & 69.1 & 8.6 & ns \\
\hline 23 & No ID & Avidin & 86.4 & 83.8 & 12.3 & ns \\
\hline & & $\mathrm{CCB}$ & 63.6 & 79.6 & 12.5 & ns \\
\hline 24 & Properdin factor B & Avidin & 37.5 & 88.9 & 10.8 & 0.01 \\
\hline & & $\mathrm{CCB}$ & 28.1 & 23.1 & 3.2 & ns \\
\hline 25 & Mixture: alpha & Avidin & 32.1 & 54.6 & 10.7 & ns \\
\hline & of carbonic anhydrase & & & & & \\
\hline & & $\mathrm{CCB}$ & 105.7 & 89.5 & 12.7 & ns \\
\hline 26 & No ID & Avidin & 5.8 & 10.6 & 1.2 & 0.03 \\
\hline & & $\mathrm{CCB}$ & 18.0 & 15.4 & 4.1 & ns \\
\hline 27 & Angiotensinigen & Avidin & 49.4 & 74.0 & 9.4 & ns \\
\hline & & $\mathrm{CCB}$ & 71.5 & 61.3 & 7.5 & ns \\
\hline 28 & Alpha-1-acid & Avidin & 382.5 & 441.8 & 62.6 & ns \\
\hline & & $\mathrm{CCB}$ & 455.3 & 526.0 & 74.6 & ns \\
\hline 29 & Fetuin A & Avidin & 739.9 & 996.5 & 108.2 & ns \\
\hline & & $\mathrm{CCB}$ & 1114.9 & 1284.4 & 106.8 & ns \\
\hline 30 & Alpha fetoprotein & Avidin & 719.2 & 646.1 & 124.8 & ns \\
\hline & & $\mathrm{CCB}$ & 1537.2 & 1380.8 & 103.9 & ns \\
\hline 31 & $\begin{array}{l}\text { Alpha-1-acid } \\
\text { glycoprotein }\end{array}$ & Avidin & 547.8 & 577.6 & 68.8 & ns \\
\hline & & $\mathrm{CCB}$ & 662.6 & 599.1 & 110.8 & ns \\
\hline 32 & No ID & Avidin & 73.1 & 68.5 & 13.3 & ns \\
\hline & & $\mathrm{CCB}$ & 67.9 & 74.3 & 20.5 & ns \\
\hline 33 & Fetuin B & Avidin & 457.7 & 678.0 & 60.9 & 0.04 \\
\hline & & $\mathrm{CCB}$ & 300.3 & 317.5 & 21.0 & ns \\
\hline 34 & Apolipoprotein $\mathrm{H}$ & Avidin & 12.5 & 16.6 & 2.3 & ns \\
\hline & & $\mathrm{CCB}$ & 55.3 & 57.3 & 10.7 & ns \\
\hline
\end{tabular}

Table 2 (continued)

\begin{tabular}{|c|c|c|c|c|c|c|}
\hline \multirow[t]{2}{*}{ Gel spot } & \multirow[t]{2}{*}{ Protein ID } & \multirow[t]{2}{*}{ Stain } & 50 days & 100 days & $\mathrm{PSE}^{1}$ & \multirow[t]{2}{*}{$P<:^{2}$} \\
\hline & & & \multicolumn{3}{|c|}{ Spot volumes } & \\
\hline \multirow{2}{*}{35} & Fetuin B & Avidin & 1045.9 & 778.5 & 100.1 & ns \\
\hline & & $\mathrm{CCB}$ & 655.4 & 634.1 & 42.3 & ns \\
\hline \multirow[t]{2}{*}{36} & $\begin{array}{l}\text { Complement component } \\
3 \text { (N-terminal fragment) }\end{array}$ & Avidin & 30.1 & 23.4 & 3.9 & ns \\
\hline & & $\mathrm{CCB}$ & 53.2 & 52.0 & 27.2 & ns \\
\hline
\end{tabular}

All listed proteins met the strict criteria for significant positive identifications as described in Materials and methods. All represent primary matches directly to Sus scrofa, except apolipoprotein $\mathrm{H}$, which was a Bos taurus match. Fetuin B and angiotensinogen were identified by searching the EST-chordata data base and obtaining significant matches to porcine EST submissions, which were BLASTED to all non redunatant sequences and identified using complete bovine sequences.

${ }^{1} \mathrm{PSE}$; pooled standard error.

${ }^{2} P<$ :, significance values obtained via analysis of variance.

${ }^{3}$ ns; not significant, $P>.05$.

${ }^{4}$ No ID; protein was not identified.

followed by total protein stain (Coomassie blue) allows for a direct comparison of the oxidized state and corresponding total amount of a specific protein within the same gel. This method eliminates the requirement of performing western blot analysis (immuno-detection of DNP conjugates) and avoids the compounded inaccuracies of comparing different gels for total protein and carbonyls. It also facilitates a direct comparison of single 2D gels and allows for more accurate spot picking for subsequent MS analysis (Poon et al., 2007). In our hands, fixation prior to addition of FITC-avidin stain was critical to allow for adequate de-staining and eliminated loss of protein via diffusion processes when each gel was re-stained with Coomassie blue (data not shown).

Protein carbonyls were detected in all pigs investigated between fetal $\mathrm{d} 50$ and postnatal $\mathrm{d} 21$, and found to be relatively constant throughout this time frame. Moreover, levels of oxidized proteins in the serum of fetal pigs, was found to be comparable to that in neonates. This suggests that the same oxidative mechanisms involved in the production of and degradation of circulating protein carbonyls are present in utero and subsequently in post uterine life. In addition to protein turnover events, the observed levels of oxidized proteins are influenced by overall antioxidant defense systems and susceptibility of specific proteins to oxidative attack (Nyström, 2005).

This is the first report of protein carbonyls in serum of pigs from any age and while carbonyls have been investigated in fetal tissues of rats (Langley-Evans et al., 2006) and plasma of fetal lambs (Cheah et al, 2008), many investigations of human serum (or plasma) have focused on the period of time directly surrounding the birthing process (Marzocchi, et al., 2005; Žitňanová et al., 2007; Mocatta et al., 2004). During birth in humans, oxidative stress has been associated with an increase in the level of protein carbonyls (Marzocchi et al., 2005), and this has been shown to be attenuated by caesarian delivery (Sridhar et al., 2007). In the present study, we did not attempt to manipulate the farrowing process, but since the carbonyl levels did not change between late fetal, early post birth and at 1 week, we conclude that under our growth conditions the observed levels of oxidized proteins are at a steady state level. It has been reported that premature infants demonstrate high levels of oxidative stress (Buonocore et al., 2002) and that small for gestational age babies have higher levels of circulating protein carbonyls at birth than average weight babies (Sridhar et al., 2007); however, this was not the case for low birth-weight (runt) piglets in the present study. Since in both pigs and humans low birthweight neonates result from uterine insufficiency this explanation alone cannot be responsible for the elevated oxidized protein levels seen in low birth weight human infants. In addition, not all studies are in agreement and Mocatta et al. (2004) have reported that early preterm infants (32 weeks) had lower levels of circulating protein carbonyls than older or at-term infants. Our results clearly demonstrate that the 

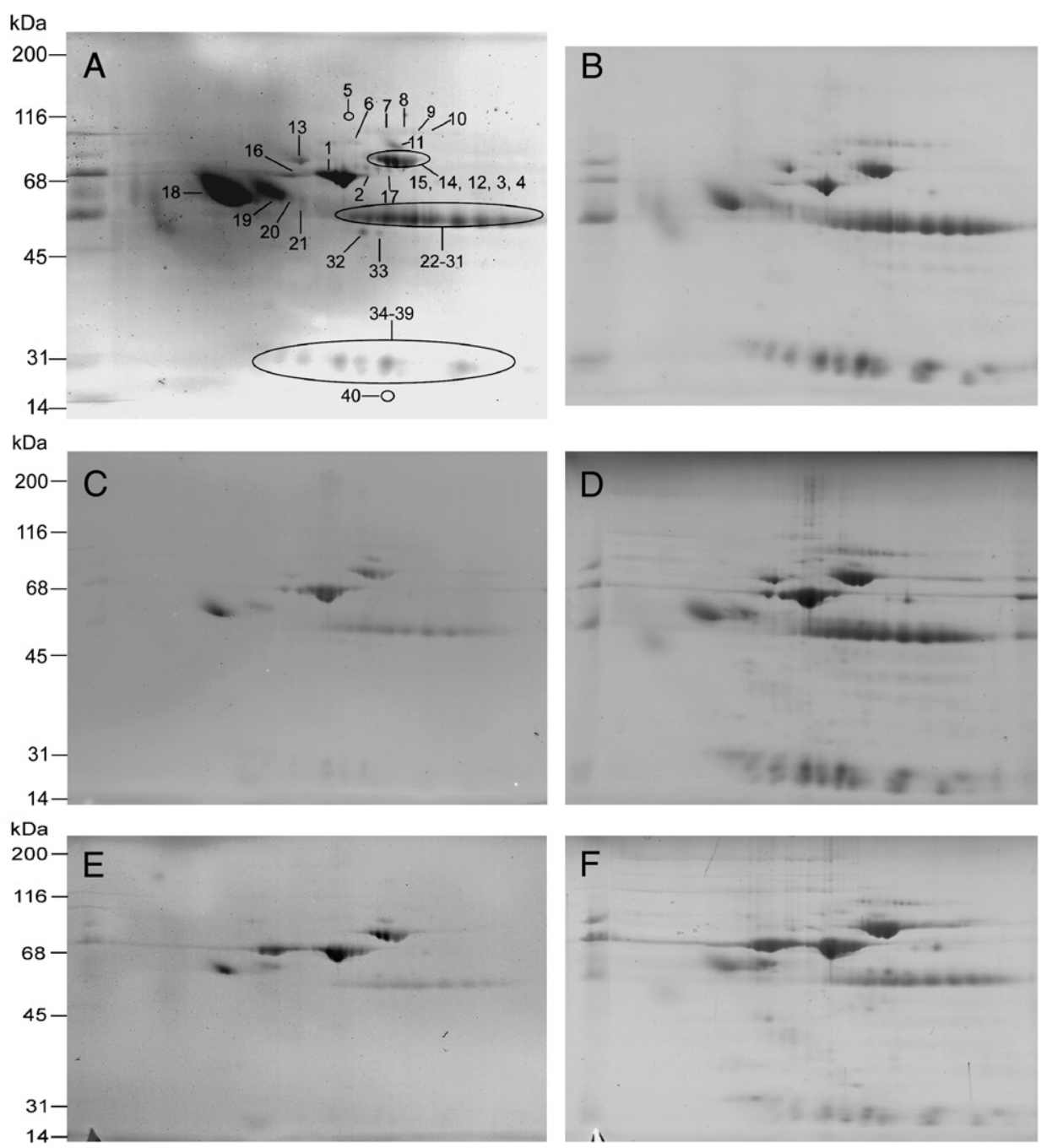

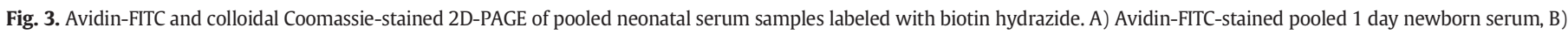

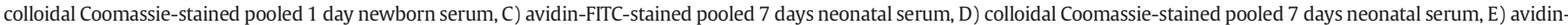

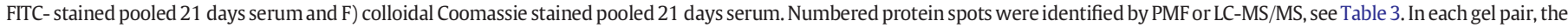
same gel was stained with avidin-FITC and colloidal Coomassie blue.

levels of carbonylated proteins were similar in middle to late aged fetuses as well as in runts and normal-weight pigs at birth.

In this investigation, serum proteins were resolved by 2D gel electrophoresis and the major oxidized serum proteins in both fetal and neonatal piglets were identified by MS. The pattern of distribution of protein carbonyls from fetal pigs was different from postnatal pigs, which appears to be reflective of the differences in protein expression in fetal pigs compared with neonates. The most obvious differences in the major proteins of fetal serum compared to neonates is the presence of fetuin $B$, higher levels of alpha-1-acid glycoprotein and fetuin $\mathrm{A}$, which all appear to decline from fetal to late neonatal life. In addition, the lack of immunoglobulins in fetal serum was also confirmed.

With few exceptions, the levels of protein carbonyls appear to be highly correlated with the levels and changes of the specific protein content at each age investigated. The changes in concentration of the major serum proteins identified over time following birth (viz., albumin, imunnoglobulins, transferrin, etc.) were similar to those reported by Martin et al. (2005) using quantitative immunological techniques. This finding suggests that the precipitation, labeling, electrophoresis and staining steps performed in the current study did not negatively impact the distribution of major proteins as they appear in a whole nonfractionated serum sample.
The distribution of serum proteins as analyzed by 2D PAGE in the present study was found to be similar among runt and average weight piglets. In a recent study of $\mathrm{Wu}$ and co-workers (Wang et al., 2008) where proteome differences in tissues of runt and normal pigs were investigated, it was suggested that runts might be subject to higher systemic oxidative stress. These conclusions were based on changes in the expression of hepatic and muscle peroxiredoxin-1, transferrin and $\zeta$ crystallin, proteins which comprise several components of the complex cellular oxidative defense system (Wang et al., 2008). If levels of circulating protein carbonyls are indeed an indication of overall oxidative stress and protein damage (Nyström, 2005) then the data presented here suggest that increased oxidative metabolism or sensitivity alone, cannot explain differences in growth performance in runt piglets. Although, the possibility that runts may be more sensitive to disease or environmental stresses cannot be ruled out.

In conclusion, we have shown that the levels of protein carbonyls remained relatively constant in piglets throughout the late fetal development and during pre-weaning growth. Most of the major serum proteins contain some level of this post-translational modification and the distribution in general follows the changes in the serum protein profile during fetal and neonatal life. Two potential specific upregulated carbonylated markers were observed in runts at birth (spots 32 \& 33, Fig. 3A), but will require additional studies to isolate and 
Table 3

Protein identification and distribution of carbonylated (avidin-stained) and total (CCB-stained) proteins in serum of control (C) and runt (R) piglets at 1,7 and 21 days of age.

\begin{tabular}{|c|c|c|c|c|c|c|c|c|c|c|c|c|}
\hline \multirow{3}{*}{ Gel spot } & \multirow{3}{*}{ Protein ID } & \multirow{3}{*}{ Stain } & \multicolumn{7}{|c|}{ Experimental groups } & \multicolumn{3}{|l|}{$P<:^{2}$} \\
\hline & & & $\mathrm{d} 1 \mathrm{R}$ & $\mathrm{d} 1 \mathrm{C}$ & d7R & d7C & $\mathrm{d} 21 \mathrm{R}$ & $\mathrm{d} 21 \mathrm{C}$ & $\overline{\text { PSE }^{1}}$ & $\overline{\mathrm{BW}^{3}}$ & Age & $\overline{B W \times \text { age }}$ \\
\hline & & & \multicolumn{7}{|c|}{ Spot volumes } & & & \\
\hline 2 & & Avidin & 52.5 & 51.2 & 116.3 & 73.6 & 166.1 & 142.5 & 35.7 & ns & 0.05 & ns \\
\hline 1,2 & & CCB & 1050.1 & 1411.6 & 2418.0 & 2191.0 & 3550.1 & 3758.2 & 607.1 & ns & 0.01 & ns \\
\hline 3 & Transferrin & Avidin & 231.8 & 189.0 & 157.4 & 197.6 & 356.2 & 328.9 & 31.5 & ns & 0.01 & ns \\
\hline 4 & & Avidin & 110.6 & 66.1 & 92.2 & 90.4 & 150.1 & 124.5 & 20.7 & ns & ns & ns \\
\hline & & $\mathrm{CCB}$ & 14.4 & 8.8 & 17.9 & 13.9 & 21.6 & 19.2 & 4.0 & ns & ns & ns \\
\hline 6 & No ID & Avidin & 32.8 & 29.6 & 24.5 & 32.8 & 16.0 & 17.9 & 2.3 & ns & 0.01 & ns \\
\hline & & ССВ & 101.2 & 86.2 & 68.8 & 98.2 & 143.9 & 116.5 & 21.8 & ns & ns & ns \\
\hline 7 & No ID & Avidin & 17.9 & 16.2 & 11.9 & 20.9 & 16.1 & 15.6 & 5.4 & ns & ns & ns \\
\hline & & $\mathrm{CCB}$ & 48.4 & 56.2 & 49.5 & 53.2 & 37.1 & 36.2 & 4.1 & ns & 0.01 & ns \\
\hline 8 & Plasminogen & Avidin & 18.9 & 10.8 & 12.6 & 19.3 & 17.2 & 16.3 & 5.1 & ns & ns & ns \\
\hline & & CCB & 47.7 & 52.1 & 53.8 & 44.1 & 28.9 & 34.6 & 6.8 & ns & 0.04 & ns \\
\hline 12 & Transferrin & Avidin & 244.5 & 214.0 & 184.4 & 251.9 & 426.9 & 405.1 & 53.2 & ns & 0.01 & ns \\
\hline & & $\mathrm{CCB}$ & 401.7 & 430.8 & 467.8 & 421.8 & 597.2 & 675.4 & 61.0 & ns & 0.01 & ns \\
\hline 13 & Alpha fetoprotein & Avidin & 153.5 & 127.2 & 87.0 & 79.7 & 36.2 & 145.1 & 35.6 & ns & ns & ns \\
\hline & & $\mathrm{CCB}$ & 489.1 & 408.4 & 389.9 & 361.6 & 136.2 & 412.9 & 88.3 & ns & ns & ns \\
\hline 14 & Transferrin & Avidin & 184.1 & 158.2 & 145.8 & 199.1 & 300.5 & 278.7 & 38.8 & ns & ns & ns \\
\hline & & $\mathrm{CCB}$ & 199.3 & 211.1 & 242.7 & 207.2 & 301.1 & 319.7 & 27.4 & ns & 0.01 & ns \\
\hline 15 & Transferrin & Avidin & 114.7 & 95.2 & 77.7 & 99.5 & 121.5 & 111.2 & 16.7 & ns & ns & ns \\
\hline & & $\mathrm{CCB}$ & 110.7 & 108.4 & 118.6 & 113.6 & 151.6 & 143.0 & 22.9 & ns & ns & ns \\
\hline 16 & Albumin & Avidin & 62.3 & 51.9 & 102.5 & 143.4 & 202.9 & 228.8 & 56.0 & ns & 0.05 & ns \\
\hline & & CCB & 87.0 & 63.0 & 163.5 & 187.1 & 272.5 & 213.6 & 46.6 & ns & 0.02 & ns \\
\hline 17 & Albumin & Avidin & 22.7 & 36.6 & 56.8 & 30.8 & 135.8 & 75.4 & 26.5 & ns & 0.04 & ns \\
\hline & & СCB & 45.6 & 52.0 & 98.8 & 68.7 & 214.5 & 143.3 & 37.7 & ns & 0.02 & ns \\
\hline 18 & Fetuin A & Avidin & 3312.9 & 2367.1 & 1333.8 & 1749.7 & 1188.4 & 1179.5 & 299.2 & ns & 0.01 & ns \\
\hline & & $\mathrm{CCB}$ & 2351.1 & 1518.8 & 1237.9 & 1132.7 & 992.4 & 1215.2 & 126.5 & 0.04 & 0.01 & 0.01 \\
\hline 19 & Alpha-1-antichymotrypsin 3 & Avidin & 376.2 & 268.2 & 158.3 & 213.4 & 335.8 & 148.9 & 78.6 & ns & ns & ns \\
\hline & & $\mathrm{CCB}$ & 604.9 & 799.7 & 599.2 & 677.0 & 386.4 & 402.9 & 57.0 & ns & 0.01 & ns \\
\hline 25 & Ig gamma chain $6 a$ & Avidin & 198.2 & 200.8 & 170.6 & 274.4 & 125.3 & 130.7 & 22.5 & ns & 0.01 & 0.03 \\
\hline & & $\mathrm{CCB}$ & 339.5 & 472.1 & 358.0 & 425.6 & 217.2 & 270.1 & 33.3 & 0.01 & 0.01 & ns \\
\hline 26 & Ig gamma-chain & Avidin & 462.1 & 490.6 & 524.2 & 535.3 & 310.7 & 291.0 & 73.2 & ns & 0.03 & ns \\
\hline & & $\mathrm{CCB}$ & 473.0 & 621.1 & 442.7 & 530.6 & 329.7 & 375.2 & 39.8 & 0.02 & 0.01 & ns \\
\hline 27 & Ig gamma-chain & Avidin & 406.1 & 401.4 & 254.4 & 412.8 & 232.1 & 227.5 & 34.0 & ns & 0.01 & ns \\
\hline & & $\mathrm{CCB}$ & 230.6 & 316.1 & 230.2 & 260.9 & 155.5 & 205.9 & 29.3 & 0.04 & 0.03 & ns \\
\hline 28 & Ig gamma-chain & Avidin & 431.3 & 455.5 & 253.0 & 437.6 & 236.9 & 251.5 & 43.0 & ns & 0.01 & ns \\
\hline & & $\mathrm{CCB}$ & 717.8 & 924.9 & 660.4 & 773.4 & 503.4 & 531.2 & 68.6 & ns & 0.01 & ns \\
\hline 29 & Ig gamma-chain & Avidin & 342.8 & 396.6 & 217.1 & 366.3 & 188.2 & 224.0 & 33.7 & 0.02 & 0.01 & ns \\
\hline & & $\mathrm{CCB}$ & 763.3 & 898.6 & 663.5 & 784.2 & 478.2 & 510.8 & 41.1 & 0.02 & 0.01 & ns \\
\hline 30 & Ig gamma-chain & Avidin & 505.7 & 528.9 & 311.0 & 447.9 & 255.8 & 278.1 & 40.4 & ns & 0.01 & 0.04 \\
\hline 31 & & Avidin & 59.0 & 73.1 & 49.7 & 48.5 & 29.4 & 27.1 & 6.8 & ns & 0.01 & ns \\
\hline 30,31 & & $\mathrm{CCB}$ & 556.3 & 663.6 & 561.9 & 591.1 & 382.8 & 422.3 & 40.0 & ns & 0.01 & ns \\
\hline 32 & No ID & Avidin & 46.9 & 25.7 & 14.9 & 13.2 & 8.4 & 7.7 & 3.1 & 0.01 & 0.01 & 0.01 \\
\hline & & СCB & 38.6 & 23.0 & 17.6 & 18.4 & 17.4 & 29.7 & 6.7 & ns & ns & ns \\
\hline 33 & No ID & Avidin & 49.2 & 16.6 & 9.4 & 6.5 & 6.1 & 5.7 & 2.6 & 0.01 & 0.01 & 0.01 \\
\hline & & $\mathrm{CCB}$ & 20.2 & 18.1 & 20.8 & 19.5 & 24.4 & 23.2 & 2.8 & ns & ns & ns \\
\hline 34 & Ig lambda chain & Avidin & 40.1 & 67.9 & 42.4 & 31.8 & 23.2 & 17.2 & 11.1 & ns & 0.04 & ns \\
\hline & & $\mathrm{CCB}$ & 184.4 & 282.0 & 179.9 & 208.8 & 75.8 & 99.4 & 37.0 & ns & 0.01 & ns \\
\hline 35 & Ig kappa chain & Avidin & 82.9 & 108.6 & 73.5 & 64.1 & 36.2 & 30.2 & 16.5 & ns & 0.01 & ns \\
\hline & & СCB & 184.4 & 282.0 & 179.9 & 208.8 & 75.8 & 99.4 & 37.0 & ns & 0.01 & ns \\
\hline 36 & Ig lambda chain & Avidin & 183.6 & 208.7 & 153.5 & 109.5 & 67.2 & 46.4 & 33.6 & ns & 0.01 & ns \\
\hline & & ССB & 385.4 & 604.6 & 426.3 & 508.9 & 213.9 & 195.4 & 72.0 & ns & 0.01 & ns \\
\hline 37 & Ig lambda chain & Avidin & 94.8 & 104.7 & 71.4 & 68.9 & 68.9 & 33.8 & 21.7 & ns & ns & ns \\
\hline & & $\mathrm{CCB}$ & 213.8 & 241.8 & 173.0 & 182.1 & 70.0 & 77.1 & 31.8 & ns & 0.01 & ns \\
\hline 38 & Ig lambda chain & Avidin & 360.5 & 380.9 & 296.7 & 253.8 & 145.4 & 113.7 & 67.7 & ns & 0.02 & ns \\
\hline & & ССВ & 592.1 & 807.3 & 516.7 & 611.5 & 243.2 & 299.3 & 77.7 & ns & 0.01 & ns \\
\hline
\end{tabular}


Table 3 (continued)

\begin{tabular}{|c|c|c|c|c|c|c|c|c|c|c|c|c|}
\hline \multirow{3}{*}{ Gel spot } & \multirow{3}{*}{ Protein ID } & \multirow{3}{*}{ Stain } & \multicolumn{7}{|c|}{ Experimental groups } & \multicolumn{3}{|l|}{$P<:^{2}$} \\
\hline & & & $\mathrm{d} 1 \mathrm{R}$ & d1C & $\mathrm{d} 7 \mathrm{R}$ & d7C & $\mathrm{d} 21 \mathrm{R}$ & d21C & $\operatorname{PSE}^{1}$ & $\mathrm{BW}^{3}$ & Age & BW $\times$ age \\
\hline & & & \multicolumn{7}{|c|}{ Spot volumes } & & & \\
\hline 39 & Ig lambda chain & Avidin & 197.9 & 194.9 & 175.1 & 171.3 & 58.2 & 44.1 & 43.3 & ns & 0.02 & ns \\
\hline 39 & & $\mathrm{CCB}$ & 824.2 & 995.8 & 652.0 & 818.8 & 364.2 & 464.2 & 126.4 & ns & 0.01 & ns \\
\hline 40 & Apolipoprotein A1 & Avidin & 57.5 & 47.9 & 51.1 & 64.9 & 29.4 & 32.1 & 9.9 & ns & 0.04 & ns \\
\hline
\end{tabular}

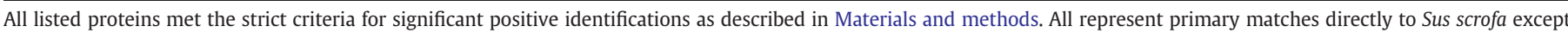

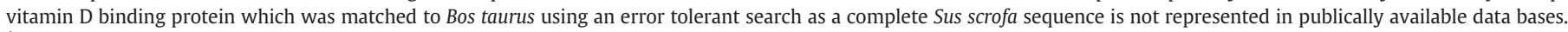
${ }^{1} \mathrm{PSE}$; pooled standard error.

${ }^{2} P<$, significance values obtained via analysis of variance.

${ }^{3} \mathrm{BW}$; birth weight (runt vs control).

${ }^{4}$ ns; not significant, $P>.05$.

${ }^{5}$ No ID; protein was not identified.

identify them. Finally, it appears that differences which occur in the physiology of runts compared to normal littermates do not reflect an overall increase in oxidative stress as determined by serum protein carbonyl analysis.

\section{Acknowledgements}

We thank Dr. Neil C. Talbot for critical review of the manuscript. We also thank Margo Stoll for animal handling, sample collection and technical assistance and Paul Graninger, Lori Schreier, and Beverly Russell for assistance in collecting fetal piglets. Jenile Tapscott, James Woods and Jim Piatt are thanked for assistance in maintaining and handling experimental animals.

\section{References}

Adams, S., Green, P., Claxton, R., Simcox, S., Williams, M.V., Walsh, K., Leeuwenburgh, C., 2001. Reactive carbonyl formation by oxidative and non-oxidative pathways. Front. Biosci. 6, a17-a24.

Buonocore, G., Perrone, S., Longini, M., Vezzosi, P., Marzocchi, B., Paffetti, P., Bracci, R., 2002. Oxidative stress in preterm neonates at birth and on the seventh day of life. Pediatr. Res. 52, 46-49.

Caperna, T.J., Shannon, A.E., Garrett, W.M., 2008. A gel-based reference map of the porcine hepatocyte proteome. Domest. Anim. Endocrinol. 35, 142-156.

Cheah, F.-C., Jobe, A.H., Moss, T.J., Newnham, J.P., Kallapur, S.G., 2008. Oxidative stress in fetal lambs exposed to intra-amniotic endotoxin in a chorioamnionitis model. Pediatr. Res. 63, 274-279.

Dalle-Donne, I., Aldini, G., Carini, M., Colombo, R., Rossi, R., Milzani, A., 2006. Protein carbonylation, cellular dysfunction, and disease progession. J. Cell. Mol. Med. 10, 389-406.

Hernebring, M., Brolén, G., Aguilaniu, H., Semb, H., Nyström, T., 2006. Elimination of damaged proteins during differentiation of embryonic stem cells. Proc. Natl Acad. Sci. U. S. A. 103, 7700-7705.

Langley-Evans, S.C., Lilley, C., McMullen, S., 2006. Maternal protein restriction and fetal growth: lack of evidence of a role for homocysteine in fetal programming. Br. J. Nutr. 96, 578-586.

Levine, R.L., Garland, D., Oliver, C.N., Amici, A., Climent, I., Lenz, A.-G., Ahn, B.-W., Shaltiel, S., Stadtman, E.R., 1990. Determination of carbonyl content in oxidatively modified proteins. Meth. Enzymol. 186, 464-478.
Martin, M., Tesouro, M.A., González-Ramón, N., Piñeiro, A., Lampreave, F., 2005. Major plasma proteins in pig serum during postnatal development. Reprod. Fertil. Dev. 17 439-445.

Marzocchi, B., Perrone, S., Paffetti, P., Magi, B., Bini, L., Tani, C., Longini, M., Buonocore, G., 2005. Nonprotein-bound iron and plasma protein oxidative stress at birth. Pediatr. Res. 58, 1295-1299.

Mocatta, T.J., Winterbourn, C.C., Inder, T.E., Darlow, B.A., 2004. The effect of gestational age and labour on markers of lipid and protein oxidation in cord plasma. Free Radic Res. 38, 185-191.

Nakamura, M., Tsumoto, K., Ishimura, K., Kumagai, I., 2002. Detection of biotinylated proteins in polyacrylamide gels using an avidin-fluorescein conjugate. Anal. Biochem. 304, 231-235.

Nerurkar, L.S., Marino, P.A., Adams, D.O., 1981. Quantification of selected intracellular and secreted hydrolases of macrophages. In: Herscowitz, H.B., Holden, H.T. Bellanti, J.A., Ghaffer, A. (Eds.), Manual of Macrophage Methodology. Marcel Dekker, Inc., pp. 229-247.

Nyström, T., 2005. Role of oxidative carbonylation in protein quality control and senescence. EMBO J. 24, 1311-1317.

Perkins, D.N., Pappin, D.J.C., Creasy, D.M., Cottrell, J.S., 1999. Probability-based protein identification by searching sequence databases using mass spectrometry data Electrophoresis 20, 3551-3567.

Poon, H.F., Abdullah, L., Reed, J., Doore, S.M., Laird, C., Mathura, V., Mullan, M., Crawford F., 2007. Improving image analysis in 2DGE-based redox proteomics by labeling protein carbonyl with fluorescent hydroxylamine. Biol. Proced. Online. 9, 65-72.

Schlosser, A., Volkmer-Engert, R., 2003. Volatile polydimethylcyclosiloxanes in the ambient laboratory air identified as source of extreme background signals in nanoelectrospray mass spectrometry. J. Mass Spectrom. 38, 523-525.

Stadtman, E.R., Levine, R.L., 2000. Protein oxidation. Ann. NY Acad. Sci. 899, 191-208.

Sridhar, M.G., Setia, S., John, M., Bhat, V., Nandeesha, H., Sathiyapriya, V., 2007. Oxidative stress varies with the mode of delivery in intrauterine growth retardation: association with Apgar score. Clin. Biochem. 40, 688-691.

Wang, J., Chen, L., Li, D., Yin, Y., Wang, X., Li, P., Dangott, L.J., Hu, W., Wu, G., 2008. Intrauterine growth restriction affects the proteomes of the small intestine, liver, and skeletal muscle in newborn pigs. J. Nutr. 138, 60-66.

Yoo, B.-S., Regnier, F.E., 2004. Proteomic analysis of carbonylated proteins in twodimensional gel electrophoresis using avidin-flourescein affinity staining. Electrophoresis 25, 1334-1341.

Žitňanová, I., Sumegová, K., Šimko, M., Maruniaková, A., Chovanová, Z., Chavko, M., Ďuračková, Z., 2007. Protein carbonyls as a biomarker of foetal-neonatal hypoxic stress. Clin. Biochem. 40, 567-570. 